\title{
You and Me Against the World: Biographical Narrative Analysis on Same-Sex Couples' Experiences in the Philippines
}

\author{
Darius E. Montaño' \\ Jabin J. Deguma ${ }^{2^{*}}$ \\ Melona C. Deguma² \\ Reylan G. Capuno ${ }^{2}$ \\ Ricardo Q. Ybañez ${ }^{2}$ \\ Charisma G. Lumayag² \\ Mary Anne C. Villaganas ${ }^{2}$ \\ Niña Rozanne T. Delos Reyes ${ }^{2}$ \\ ${ }^{1}$ University of Antique, Sibalom, 5713 Antique, Philippines \\ ${ }^{2}$ Cebu Technological University, M. J. Cuenco Ave, Cebu City, 6ooo Cebu, Philippines \\ ${ }^{*}$ Corresponding Author
}

DOI: https://doi.org/10.36941/ajis-2022-0015

\begin{abstract}
This article contributes to the emerging literature on gender studies, in general, and on the LGBTQ+ phenomenon, in particular. While the global society recognizes the rights of the third sex, other countries are reluctantly acknowledging while inadvertently stigmatizing LGBTQ+ individuals. Unfortunately, some Filipino same-sex couples were still the target of ridicule, criticism, and prejudice. In this paper, we analyzed via a biographical narrative the relationship dynamics of same-sex Filipino couples confronted with homophobia, heteronormativity, and discrimination. Biographical narratives established an excellent way of making theoretical sense of social phenomena such as gender studies. To do this, we interviewed same-sex couples from the provinces of Western Visayas, Philippines. The results revealed interdisciplinary perspectives that reflected the basis for engaging and maintaining such a relationship. A recurring essence across all identified perspectives that compelled same-sex couples to stay in a relationship was their mutual love. Mutual love becomes a strong driving force that keeps the relationship between same-sex couples all the more substantial while facing heterosexual society's disapprobation. The concepts of love and friendship, by extension, genuine same-sex relationship, when properly understood, can go beyond the border of human instinctual tendencies. Such impartial manifestation of love can extend across cultural differences and eventually build crossroads as avenues of sharing what one has without counting the cost. We recommend the need to further the campaign against homophobic views, albeit providing counseling intervention and psycho-education that help improve the psychological well-being of same-sex couples.
\end{abstract}

Keywords: LGBTQ+, Same-sex Relationship, Interdisciplinary Perspective, Biographical Narrative, Psychological Well-being 


\section{Introduction}

The prevalence of same-sex unions is slowly gaining momentum in modern society. Rostosky et al. (2016) pointed out that the majority has generally accepted the third sex as lesbian or gay in the present generation. While the erstwhile disrespecting term "queer" has transformed into a word with which lesbian, gay, bisexual, and transgender (LGBTQ+) people pride in identifying themselves. Through time, the modern world gradually accepts the ubiquity of same-sex relationships. In the U.S., out of 2 million adults engaged in a same-sex relationship, approximately 780,000 are married to a same-sex spouse. (Gates \& Newport, 2013). While the Netherlands is generally known as one of the most lesbian and gay-tolerant countries in Europe (Kuezenkamp \& Kuyper, 2013). Rook (2013) cited in his study that in Spain, Germany, Canada, and the Czech they had a more considerable percentage rate of accepting homosexuality. Laws even protect same-sex couples against discrimination. They are allowed to adopt children and legally change their gender.

However, other countries are reluctantly acknowledging while inadvertently stigmatizing individuals who are members of the LGBTQ+. For example, in the Philippines, those in a same-sex relationship have been the target of ridicule, criticism, and prejudice, despite the positive pronouncement of the mainstream media that the Filipino society has accepted and tolerated the LGBTQ+ community (Lai, 2018). Homophobia remains a sensitive issue confronted by queer Filipinos. Homophobia or "gay-bashing" is culturally and socially constructed fear of or prejudice against the LGBTQ+ community that in some instances expresses itself in legal constraints or, in extreme cases, bullying or even violence against its members.

Despite widely accepted views regarding the LGBTQ+ community, most individuals are more often concerned with proving their heterosexuality because homosexuality is stigmatized. The factors that strengthen this discrimination are moral, religious, and political beliefs. Some dominant groups stereotypically labeled LGBTQ+ individuals as disgraced. Alegre (2018) stated that members of LGBTQ+ society considered religion an influential factor that floored the experience of gender discrimination in the Philippines. One must note that the Philippines is known to be a Christian nation (Deguma et al., 2019; 2020). The said survey also revealed that the participants emphasized the Holy Scripture (regardless of religion; it can be Bible, Qur'an, etc.) as the primary source of the idea that the LGBTQ+ community lived a sinful lifestyle.

Moreover, countries like Nigeria and Pakistan considered being gay illegal. Unfortunately, queer communities do not have legal protection from the government. In Senegal, for instance, there has been an increase in police brutality against gays (Rook, 2013). They cannot even cross-dress in public, and same-sex marriage is strictly prohibited. The maximum penalty for disobeying is death (Rook, 2013). Such a mindset would lead to inevitable societal discrimination against LGBTQ+ individuals indulging in a same-sex relationship. The psychosocial and political climates in which same-sex couples live affected their quality of life. These generate the dissimilarities between acceptance and legalization and discrimination and restriction of their romantic relationships. Therefore, support to same-sex couples by understanding the dynamics of their relationships dwelling in a derogatory and prejudicial social milieu is direly needed (Rostosky et al., 2006).

\section{Literature Review: Recognition and Stigmatization of Same-Sex Relationship}

The 21st century opened the advent of expanded and controversial discussions of issues and concerns related to homosexuality and its impact on family life (Biblarz \& Savci, 2010). There have been different and opposing views as regards LGBTQ+ people. Some countries favor the existence of the same-sex relationship, while some strongly condone their existence. Rupp and Haag (2016) noted the increasing number of cohabiting same-sex couples, for example, in Germany, ranged between 67,00o185,000 in 2011. However, marriage-like partnerships and cohabitation are less frequent in same-sex couples than heterosexual partnerships (Brown et al., 2019). In the Netherlands, homosexuality is broadly accepted being one of the most lesbian and gay-tolerant countries in Europe (Kuezenkamp \& 
Kuyper, 2013). Also, in Spain, Germany, Canada, and the Czech they had a more considerable percentage rate when accepting homosexuality. Favorably, the laws of the countries mentioned earlier protect same-sex couples against discrimination. They are allowed to adopt children and legally change their gender.

Interestingly, the American Psychiatric Association (APA) decided to remove homosexuality from the mental disorder list in the Diagnostic and Statistical Manual of Mental Disorders (Weill, 2009). Weill (2009) noted that such progressive action of APA marked a favorable implication of the phenomena of same-sex attraction as a "standard variant of human sexuality." Weill (2009) also underscored that APA already recognized that same-sex attraction is not a disease. Sheldon et al. (2006) posited that biological and psychosocial theories could explain the phenomenon of same-sex sexual attraction. Savic et al. (2005) investigated the human hypothalamus and brain functioning concerning same-sex sexual attraction, concentrating on reactions to common pheromones found in sexual behavior. Individuals with same-sex attraction have "showed activation in identical areas of the anterior hypothalamus when presented with the testosterone derivative" that could elicit the basis for the occurrence of such a phenomenon (Savic et al., 2005). Moreover, Forrest et al. (2019) furthered the hypothesis that such an attraction could be a paucity of "definitive biological proof," which suggested a composite synthesis of factors related to psychosocial concerns.

Albeit the recent improvements, same-sex couples still experience negative criticisms and prejudices. The experience of seemingly immanent discrimination affects the disadvantaged group, particularly individuals who are into a same-sex relationship. The studies of Jost et al. (2004) and Meyer \& Frost (2013) enumerated stigmatic circumstances pertinent to discrimination, including irrational beliefs of the immanence of the experiences of suffering and endurance of poor workrelationship conditions that resulted in inferior life quality. Cragun \& Sumerau (2015) opined that the LGBTQ+ suffered all forms of discrimination, as reflected in the infamous and obscure history accounts of bias and unfair treatment of the third-sex. For example, in Senegal, there has been an increase in police brutality against the queer community. Being gay or lesbian is considered illegal and punishable by fines, imprisonment, and even death (Rook, 2013). Also, in Nigeria and Pakistan being gay is illegal. They do not have legal protection from the government. They are not allowed to wear women's clothes in public, and same-sex marriage is strictly prohibited. The maximum penalty for disobeying is death (Rook, 2013).

But the challenges encountered by the LGBTQ+ also are at the family level. The study of Reczek (2016) found that the well-being of gay and lesbian adults is affected by parental disapproval of samesex romantic relationships. While the study of Denton et al. (2014) purported that unsupportive family members could have influenced the lower level of social acceptance of the same-sex relationship. Indeed, Same-sex relationship continues to be a controversial issue in the general public (Hank \& Wetzel, 2018). As a matter of evidence, in Germany, as cited by Steffens \& Wagner (2004), the acceptance rating of same-sex partnerships is inching despite the ubiquity of progressive movements that support LGBTQ+ rights.

To further the discussion, social media also played a role in spreading a negative message about the LGBTQ community. Such prejudice-driven information is more often than not inaccurate or harmful (Plug et al., 2014). There has been an increase in the number of queer characters illustrated on television and in movies in current years in which gay men are more often than not eroticized and depicted in a demeaning way (Westerfelhaus \& Lacroix, 2006). The idea regarding heteronormativity dominates in society that is why heterosexuality is generally portrayed and normalized. Such reflects a culture in which heterosexual males think that queer women are available for their desire and pleasure and that queer women need to be fixed by a strong, straight man (Schilt \& Westbrook, 2009).

The struggle for same-sex relationship recognition in the Philippine setting is concurrent with the fight for the rights of the third sex. One salient historical footnote of such an exertion was when the Commission on Election (COMELEC) denied the Ang Ladlad LGBT Party for accreditation as a party-list organization (Out Right Action International, 2009). The Ang Ladlad LGBT Party comprises 
men and women who identify themselves as lesbians, gays, bisexuals, or trans-gendered individuals (LGBTs). Under Republic Act (R.A.) No. 7941, otherwise known as the Party-List System Act, grants sectorial representation to realize aspirations of marginalized individuals whose interests are also the nations. Albeit, COMELEC denied the application for accreditation because the organization had no substantial membership base. The COMELEC explained that "Ang Ladlad LGBT Party (must) justify that having mixed sexual orientations and transgender identities (are) beneficial to the nation" (Manalastas \& Torre, 2013). Further, it quoted Lehman Straus saying that "older practicing homosexuals are a threat to youth." Although the Supreme Court Baguio City En Banc later reversed the decision by granting Ang Ladlad LGBT Party the application for party-list accreditation, religion, and public morals became the underlying grounds to deny the petition for registration. Philippines is one of the most religion-influenced countries in the world. It has always advocated keeping the laws of God. The religious people are against same-sex activities, for it was believed to be a big sin committed by the person involved. The critics of same-sex unions have also gone beyond debates and discourse in the past. The LGBTQ+ have been protesting for their rights and to consider the union between same-sex relationships, unfortunately, the government has no grant given to this plea (Borah, 2018). Love which is known to be unconditional, paves the way for acceptance. However, this is not the case for same-sex couples.

\section{Research Problem}

Recently there have been a few research pieces on the life world of same-sex couples in the Philippines context. Such a lack of contextual information could have contributed to what Tan (2001) opined that lack of rational views based on unfair opinions and prejudices drive stigmatization against the LGBTQ+ community. This paper attempts to understand the relationship dynamics of same-sex couples confronted with homophobia, heteronormativity, and discrimination. The study's findings contribute to the discussion by revealing interdisciplinary perspectives that reflected the basis for engaging and maintaining such a relationship.

\section{Materials and Method}

\subsection{Research design}

The study utilized the biographical narratives of the relationship dynamics of same-sex couples to reveal interdisciplinary perspectives that reflected the basis for engaging and maintaining such a relationship. Biographical narratives established an excellent way of making theoretical sense of social phenomena such as gender studies (Nohl, 2010; Smith \& Watson, 2010; Kelchtermans, 2012; Suarez-Ortega, 2013; Valentine \& Sadgrove, 2014).

Table 1: Profile of the Participants

\begin{tabular}{|c|c|c|c|}
\hline Participants & Age & Profession & Number of Years in the Relationship \\
\hline \multirow{2}{*}{$\begin{array}{l}\text { Gay Couple } 1 \\
\text { (Joe and Mike) }\end{array}$} & 34 & Human Resource Staff & \multirow{2}{*}{7} \\
\hline & 29 & Registered Nurse & \\
\hline \multirow{2}{*}{$\begin{array}{l}\text { Gay Couple } 2 \\
\text { (Andrew and Mark) }\end{array}$} & 26 & Call Center Agent & \multirow[b]{2}{*}{3} \\
\hline & 29 & Medical Transcriptionist & \\
\hline \multirow{2}{*}{$\begin{array}{l}\text { Gay Couple } 3 \\
\text { (Josh and Ralph) }\end{array}$} & 35 & Teacher & \multirow[b]{2}{*}{5} \\
\hline & 34 & College Instructor & \\
\hline \multirow{2}{*}{$\begin{array}{l}\text { Lesbian Couple } 1 \\
\text { (Anne and Marie) }\end{array}$} & 33 & Lawyer & \multirow[b]{2}{*}{4} \\
\hline & 33 & Teacher & \\
\hline \multirow{2}{*}{$\begin{array}{l}\text { Lesbian Couple } 2 \\
\text { (Grace and Joy) }\end{array}$} & 26 & Office Staff & \multirow[b]{2}{*}{5} \\
\hline & 23 & Student & \\
\hline
\end{tabular}




\begin{tabular}{|l|c|l|c|}
\hline Participants & Age & \multicolumn{1}{|c|}{ Profession } & Number of Years in the Relationship \\
\hline $\begin{array}{l}\text { Lesbian Couple } 3 \\
\text { (Cherry and Jessie) }\end{array}$ & 36 & Nurse & \multirow{2}{*}{9} \\
\cline { 2 - 3 } & 35 & Nurse & \\
\hline
\end{tabular}

\subsection{The participants}

The participants of this study were six same-sex couples composed of three gay couples and three lesbian couples from three selected provinces in Western Visayas, Philippines (see Table 1). The researchers used Pseudonyms in discussing the participants' narratives to maintain confidentiality. This study chose the participants using purposive sampling. This type of sampling technique is subjective and depends upon the researchers' judgment regarding the subject to be studied (Creswell, 2012).

\subsection{Ethical consideration}

As part of the ethical dimension of research involving human participants, the researchers asked for the approval of the same-sex couples through informed consent and scheduled the interview based on the convenient time of each participant in their respective houses. Before the start of every interview session, the researchers explained the study's objectives. The participants also permitted the audio recording of the entire interview. All respondents signed a free and prior informed consent.

\subsection{Instrument}

The research instrument is composed of two (2) parts. Specifically, part one pertained to the personal information of same-sex couples. The second part included open-ended questions to be answered by the participants. The questions were in English and the local dialect to ensure that participants could express their ideas and views well. Participants freely discussed their answers and the researchers provided in-depth questions to prompt further explanation from the participants.

\subsection{Data collection process}

In collecting the needed biographical narratives, the researcher did an in-depth interview using openended guide questions to analyze same-sex couples' experiences better. In-depth interviewing is a qualitative research technique that includes carrying out intensive individual interviews with limited participants (Creswell, 2012). Such explores the viewpoints on a specific idea or situation. Each couple was interviewed simultaneously to best capture their narratives and validate their experiences' authenticity further. The interview was divided into two separate sessions for each participant, lasting from 20 to 25 minutes per session. During the first interview session, rapport is built between the same-sex couple participants and the researcher. We asked each same-sex couple about their basic personal information using a semi-structured form. The second interview session focused on sharing their experiences as a same-sex couple using open-ended guide questions. The interview session ended with thanking the participants for sharing their stories.

\subsection{Data Analysis}

After the interview sessions, the researchers listened to the audiotapes at least one time completely before transcribing them verbatim. The researcher then followed the steps outlined by Creswell (2012) as a data analysis procedure. First, the researchers read the transcriptions several times to organize and sort the data to familiarize the researcher with it. The biographical narratives of the respondents were utilized to reveal interdisciplinary perspectives for analysis. The researchers then highlighted the different narratives of the respondents to generate initial codes. These codes led to 
the development of interdisciplinary perspectives to describe the contextual experiences of the participants. The final step was to create an overall narrative with all of the data, analyze each perspective, and accompany individual reports or quotations to support each revealed perspective. The data then revealed an invariant structure or essence, focusing on the participants' most common experiences. Ultimately, the researchers attempted to decode the conceptual paradigm into a story that is easy to understand by readers. The output will turn out to be a tightly woven interpretation that resembles the real world it manifests.

Figure 1: Framework of the Study

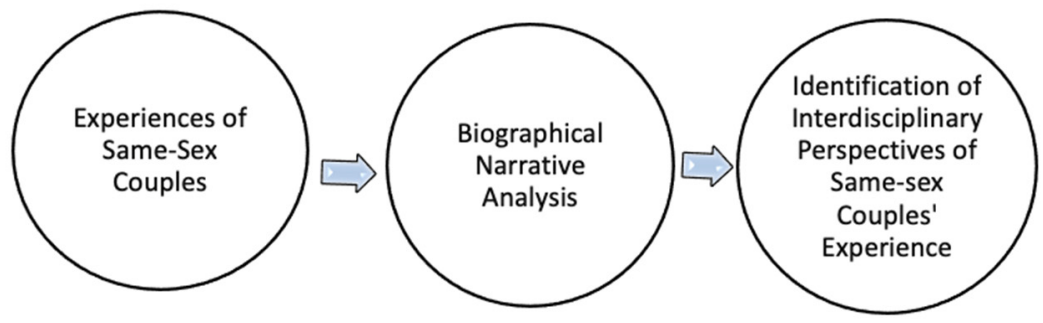

\section{Results and Discussion}

The main objective of this study was to delve into the same-sex couples' experiences to identify interdisciplinary perspectives via biographical narrative analysis. The following interdisciplinary perspectives surfaced include: 4.1) Reasons for Attractions, and Perceived Advantages, 4.2) Maintaining Relationships, and Meaning in Life; 4.3) Challenges and Ways of Coping.

\subsection{Reason for Attractions and Perceived Advantages}

The participants narrated that what attracted them most are the qualities of their partners for being supportive, kind, fun to be with, and having a sense of humor. Moreover, they examined the same-sex relationship dynamics in Northern California. The two significant attraction factors cited are 1.) agreeableness (being kind and supportive) and 2.) extraversion (fun to be with and sense of humor). Physical attractiveness ranked second, and the minor bases for the attraction were characteristics associated with financial success (Felmlee et al., 2010).

The social exchange theory popularized by Thibaut and Kelley (1959) purported that social behavior results from the give and take process. The paradigm of social exchange theory is to expound the development, the dynamics of maintaining relationships, and the decline of exchange relationships. People are inclined to develop an attraction to one another once the benefits of being in that relationship exceed the costs and even viable alternatives (Thibaut \& Kelley, 1959). Rewards denote the pleasurable and satisfying effect individuals obtain from being with another person. These also refer to the opportunities to receive desired goods, specifically finances, social status, and beauty. Conversely, costs refer to unlikable and unwanted relationships like monetary investments, relational conflict, and the probable feelings of agony and despair. The process of deducting foreseen expenses from expected rewards sets off the likely relationship outcome related to a specific prospective partner (Thibaut \& Kelley, 1959).

Peplau \& Spalding (200o) cited that many gay and lesbian relationships are similar to a model of best friendship, supplemented with romantic attraction. Such is in coherence with the study results that same-sex couples perceived the advantage of being in a relationship was their friendship toward their partner and that they had a companion when they grew old. Therefore, it is also imperative that lesbians and gays seek a relationship because of affection and the benefit of having a companion, just 
like heterosexual couples (Peplau \& Fingerhut, 2007).

In an online article, Stern (2016) purported that one of the perceived advantages of being in a same-sex relationship was eliminating feelings of distress in getting pregnant or possibly leading to being responsible for a new human being. Another advantage that same-sex couples pointed out was their satisfaction with their sex life. Stern (2016) pointed out that what made LGBTQ+ sex a distinctly different experience from straight sex was the familiarity with the territory that gave them satisfaction. In addition, same-sex couples knew what to do to make them feel good because they had already experienced those with their own body.

\subsection{Maintaining Relationships and Meaning in Life}

Despite stereotypes that LGBTQ+ members could not have enduring relationships, the study results revealed that same-sex couples had their ways of maintaining their relationships. Debunked by Peplau and Fingerhut (2007), gays and lesbians aspire to have a lasting relationship. Based on the narratives, same-sex couples were looking forward to having an enduring and lasting relationship. Individuals are inclined to develop an attraction to one another when the benefits of being in that relationship exceed the costs and even viable alternatives (Thibaut \& Kelley, 1959). Based on the transcripts, same-sex couples had their ways of maintaining their relationship.

To maintain their relationships, the participants in this study mentioned that they gave importance to their partner's positive qualities. Such is also the same with the research revealed by Regan et al. (2001), wherein LGBTQ+ members, just like heterosexuals, emphasize mental, pleasing personality, and family-centered characteristics when choosing a long-term romantic partner.

In this study, same-sex couples had a positive outlook about life regardless of the discrimination they experienced and the influence of heteronormative ideas towards other people's thinking towards them. They gathered strength from the people who accepted and gave them unconditional support like their families and trusted friends. According to Seligman et al. (2005), it is crucial to have constant social support from significant others because it would make an individual possess the character strength of love. LGBTQ+ community draws enthusiasm from the people who could understand and gave them emotional support. However, the study results were similar to the research conducted by Dean et al. (200o). It had been a test for LGBTQ+ members to maintain a positive sense despite condescending reactions founded in heteronormative beliefs.

\subsection{Challenges and Ways of Coping}

The findings of this study are congruent with the salient points cited in the study of Sowe et al. (2014) concerning internalized homophobia. There was the internalization of negative family and community attitudes towards same-sex sexual attraction (Sowe et al., 2014). Another challenge that the participants pointed out was the role of religion in perceiving same-sex relationships. Such a finding supported the claim of the Rainbow Project Survey, as cited by Pamorada (2014) and Alegre (2018) that religion could be an influential variable that impacts the lower acceptance level of the LGBTs in the Philippines. Some Filipinos had this negative attitude towards LGBTQ+ because of the taught deleterious ideas on homosexuality.

Same-sex couples found it disadvantageous to be in a same-sex relationship because people labeled them as sinners. This result was similar to the findings of Higa et al. (2014) that religious societies had consistently scorned same-sex couples because of their sexual preference. In addition, the study participants mentioned that others had labeled them as sinners because they belong to the LGBTQ+ community (Higa et al., 2014). Participants emphasized not having a child of their own as a challenge. Their incapacity to bear a child gave them feelings of insecurity and posed a challenge as a couple. They were looking forward to having a family of their own by adopting a child as an option. According to Hayes et al. (2010), a growing occurrence of same-sex parented families and same-sex couples had possibilities of adopting a child to raise their own family. 
Moreover, same-sex couples had their ways of coping. One of which was to accept and love themselves fully. Similar to the finding of Wilson \& Miller (2002), gay and bisexual men managed heterosexism by choosing to love themselves fully. These personal decisions to love themselves represent a form of change in their mindsets entirely (McDavitt et al., 2008).

Another coping mechanism mentioned by the participants in this study was avoiding situations that would make same-sex couples uncomfortable. Instead, they would associate themselves with people who could understand and accept them. These results had the same findings as the study conducted by McDavitt et al. (2008) about situation selection. Such implied avoiding situations due to the expected emotional impact. Participants usually looked for a sense of belongingness with people who acknowledged and respected their sexual identities. Those kinds of emotional support come from friends, colleagues, teachers, counselors, and family members.

This study revealed that same-sex couples advocate LGBTQ+ rights as their coping method, congruent with the research conducted by Higa et al. (2014). They cited two ways of coping with the stigma that includes acting out and advocating the rights of LGBTQ+. Self-acceptance denotes understanding themselves as distinct and unique individuals. Such also entails being comfortable with themselves (Higa et al., 2014).

\section{Implication, Conclusion and Recommendation}

Despite widely accepted views regarding LGBTQ+ people in the Philippines, same-sex relationships have been the target of criticism and discrimination. This phenomenological study aimed to discover same-sex couples' lived experiences from the selected provinces in Western Visayas. Moreover, the minority-stress model was used to elucidate the same-sex couples' lived experiences because they tend to experience more stress in their everyday living (Meyer, 2013). This study discovered that despite homophobic views resulting in stigma, discrimination, and oppressive nature on marginalized same-sex couples, they could endure their relationships. Social exchange theory may explain the reason behind sustained and committed relationships despite being marginalized. Thibaut and Kelly (1959) posited that the motivating factor for these individuals to be in such relationships is the goodness of consequences. Same-sex couples regard the worth of outcomes founded on rewards and costs, but that requires mutual activity in large proportion for the union to be enduring. For same-sex couples, being motivated and keeping their relationship may be difficult because they continue to face discrimination in many areas of their lives. However, if their partner unconditionally shows genuine love, respect, and trust, they may feel satisfied, happy, and optimistic about life. Thus, feelings of being stigmatized or discriminated against may be overshadowed.

Although there are resemblances in the overall relationship dynamics and functioning of gay, lesbian, and heterosexual, same-sex couples tend to experience more stress in their everyday lives (Meyer 2013). These individuals encounter distinct pressures such as interpersonal and institutional discrimination, which may, in turn, weaken the quality of their passionate relationship (Doyle \& Molix 2014). In addition, same-sex couples have to contend with how their friends, family members, and colleagues perceive their relationship due to the anticipated deprecation.

Nonetheless, men and women alike in this kind of relationship turn out to be comparably susceptible to many minority stressors. However, men who are in same-sex relationships bear more stress-related harassment and violence. In contrast, women in same-sex relationships carry more stress because of the adverse reactions of their families (Todosijevic et al., 2005). In addition, due to more disapprobation possibilities than heterosexual couples, same-sex couples are more likely to be less devoted to pursuing their relationship (Rostosky et al., 2016).

This endeavor offers insights for society to be enlightened concerning the biographical narratives of same-sex couples. A recurring essence across all identified perspectives that compelled same-sex couples to stay in a relationship was their mutual love. Mutual love becomes a strong driving force that keeps the relationship between same-sex couples all the more substantial while facing heterosexual society's disapprobation (Kahambing \& Deguma, 2019; Deguma et al., 2021). In 
totality, the concepts of love and friendship, by extension, genuine same-sex relationship, when properly understood, can go beyond the border of human instinctual tendencies (of loving only the adorable and befriending those who are easy to associate). Such impartial manifestation of love can extend across cultural differences and eventually build crossroads as avenues of sharing what one has without counting the cost. This study recommends counseling interventions and psycho-education can be carried out to those in a same-sex relationship to help improve their psychological well-being knowing that many of them experience discrimination. The findings of this study invite further research that may expand upon the descriptive and meaning themes presented above to provide additional and divergent conclusions contributing to the literature on same-sex couples.

\section{References}

Alegre, B. R. (2018). From bakla to transpinay: Transgender students in Philippine schools. In Routledge international handbook of schools and schooling in Asia (pp. 864-871). Routledge.

Biblarz, T.J. \& Savci, E. (2010). Lesbian, gay, bisexual, and transgender families. Journal of Marriage and Family 72(3): 480-497. doi:10.1111/j.1741-3737. 2010.00714.x

Borah, P. K. (2018). Engaging with the law: Decriminalisation of homosexuality and the Johar Judgement, 2018. Space and Culture, India, 6(3), 5-22.

Brown, C., Contreras, D., \& Schmidt, L. (2019). Sexual orientation and labor force participation: findings from Chile and Uruguay. Feminist Economics, 25(2), 90-115.

Cragun, R. T., \& Sumerau, J. E. (2015). The last bastion of sexual and gender prejudice? Sexualities, race, gender, religiosity, and spirituality in the examination of prejudice toward sexual and gender minorities. The Journal of Sex Research, 52(7), 821-834.

Creswell, J. W. (2012). Qualitative inquiry and research design: Choosing among five approaches. Thousand Oaks, CA: Sage.

Dean L., Meyer I.H., Sell, R.L., Sember, R, Silenzio, V., Bowen, D.J. (200o). Lesbian, gay, bisexual, and transgender health: Findings and concerns. Journal of the Gay and Lesbian Medical Association. 4:101-151

Deguma, J. J., Case, M. S., \& Tandag, J. N. (2019). Popular Religiosity: Experiencing Quiapo and Turumba. Online], American Research Journal of Humanities \& Social Science (ARJHSS), 2(6), 1-11.

Deguma, J. J., Deguma, M. C., Tandag, J. N., \& Acebes, H. M. B. (2020). Where is the Church in the Time of COVID-19 Pandemic: Preferring the Poor via G. Gutierrez' Liberation and the Catholic Church's Social Teaching in the Philippine Setting. Journal of Social and Political Sciences, 3(2).

Deguma, J. J., Capuno, R. G., Deguma, M. C., Manguilimotan, R. P., Espina, R. C., \& Padillo, G. G. (2021). An Analogical Investigation of the Pythagorean Triangle: From a Mathematical Figure to an Ethical Praxis. Academic Journal of Interdisciplinary Studies, 10(1), 373-373.

Denton, F. N., Rostosky, S. S., \& Danner, F. (2014). Stigma-related stressors, coping self-efficacy, and physical health in lesbian, gay, and bisexual individuals. Journal of counseling psychology, 61(3), 383 .

Doyle D.M., Molix, L. (2014). Love on the margins: The effects of social stigma and relationship length on romantic relationship quality. Social Psychological and Personality Science. 5:102-110. doi: 10.1177/1948550613486677.

Felmlee, D., Orzechowicz, D., \& Fortes, C. (2010). Fairy Tales: Attraction and Stereotypes in Same-Gender Relationships. Sex roles, 62(3-4), 226-240. doi:10.1007/s11199-009-9701-x

Forrest, J., Gorman-Murray, A., \& Siciliano, F. (2019). The geography of same-sex couples and families in Australia: an empirical review. Australian Geographer, 50(4), 493-509.

Gates, G. J. \& Newport, F. (2013). Special report: 3.4\% of U.S. adults identify as LGBT. Gallup, Retrieved from http://www.gallup.com/poll/158066/special-report-adults-identify-lgbt.aspx

Hank, K., \& Wetzel, M. (2018). Same-sex relationship experiences and expectations regarding partnership and parenthood. Demographic Research, 39, 701-718.

Hayes, A., Weston, R., Qu, L., \& Gray, M. (2010). Families then and now: 1980-2010 (Facts Sheet). Melbourne: Australian Institute of Family Studies.

Higa, D., Hoppe, M. J., Lindhorst, T., Mincer, S., Beadnell, B., Morrison, D. M., \& Mountz, S. (2014). Negative and Positive Factors Associated With the Well-Being of Lesbian, Gay, Bisexual, Transgender, Queer, and Questioning (LGBTQ) Youth. Youth \& society, 46(5), 663-687. doi:10.1177/oo44118X12449630

Jost, J. T., Banaji, M. R., \& Nosek, B. A. (2004). A decade of system justification theory: Accumulated evidence of conscious and unconscious bolstering of the status quo. Political psychology, 25(6), 881-919. 
Kahambing, J. G. S., \& Deguma, J. J. (2019). Reflecting on the Personality of Artificiality: Reading Asimov's Film Bicentennial Man through Machine Ethics. Journal of Educational and Social Research, 9(2), $17-17$.

Kelchtermans, G. (2012). Teachers and their career story: A biographical perspective on professional development. In Research on Teacher Thinking (RLE Edu N) (pp. 206-228). Routledge.

Keuzenkamp, S., \& Kuyper, L. (2013). Acceptance of lesbians, gays, bisexuals and transgender individuals in the Netherlands 2013. The Hague: The Netherlands Institute for Social Research | SCP.

Lai, F. Y. (2018). Migrant and lesbian activism in Hong Kong: a critical review of grassroots politics. Asian Anthropology, 17(2), 135-150.

Manalastas, E. J. D., \& Torre, B. A. (2013). Social Psychological Aspects of Advocating LGBT Human Rights in the Philippines. Gender and Justice Action Research Program, Institute of Human Rights, University of the Philippines Law Center.

McDavitt, B., Iverson, E., Kubicek, K., Weiss, G., Wong, C. F., \& Kipke, M. D. (20o8). Strategies Used by Gay and Bisexual Young Men to Cope with Heterosexism. Journal of gay \& lesbian social services, 20(4), 354-38o. doi:10.1080/10538720802310741

Meyer I.H., Frost D.M. (2013). Minority stress and the health of sexual minorities. In: Patterson CJ, D'Augelli AR, editors. Handbook of psychology and sexual orientation. New York: Oxford University Press. pp. 252-266.

Nohl, A. M. (2010). Narrative interview and documentary interpretation (pp. 195-217). B. Budrich.

Out Right Action International. (2009). Philippines: COMELEC Denies Accreditation to Ang Ladlas LGBT Party. Retrieved from https://outrightinternational.org/content/philippines-comelec-denies-accreditation-angladlad-lgbt-party

Pamorada, E. (2014). The Rainbow Project Survey Conducted on LGBTs in the Philippines: Results and Analysis in 2014. Retrieved from https://therainbowprojectph.wordpress.com/2014/o8/28/survey-conducted-on-lgbtsin-the-philippines-results-and-analysis/

Peplau L.A., Fingerhut, A.W. (2007). The close relationships of lesbians and gay men. Annual Review of Psychology. 58:405-424. doi: 10.1146/annurev.psych.58.110405.085701

Peplau L.A., Spalding L.R. (200o). The close relationships of lesbians, gay men, and bisexuals. In: Henrick CA, Singer H.S., editors. Close Relationships: A Sourcebook. Thousand Oaks: Sage. pp. 111-123.

Plug, E., Webbink, D., \& Martin, N. (2014). Sexual orientation, prejudice, and segregation. Journal of Labor Economics, 32(1), 123-159.

Reczek, C. (2016). Parental disapproval and gay and lesbian relationship quality. Journal of family issues, 37(15), 2189-2212.

Regan P.C., Medina, R., Joshi, A. (2001). Partner preferences among homosexual men and women: What is desirable in a sex partner is not necessarily desirable in a romantic partner. Social Behavior and Personality: An International Journal. doi: 10.2224/sbp.2001.29.7.625

Rook, E. (2013). A global perspective: LGBT equality around the world. Retrieved February 5February 5, 2019, from https://erinrook.com/2013/o6/13/a-global-perspective-lgbt-equality-around-the-world/

Rostosky, S. S., Riggle, E. D., Dudley, M. G., \& Wright, M. L. C. (2006). Commitment in same-sex relationships: A qualitative analysis of couples' conversations. Journal of Homosexuality, 51(3), 199-223.

Rostosky, S. S., Riggle, E. D., Rothblum, E. D., \& Balsam, K. F. (2016). Same- sex couples' decisions and experiences of marriage in the context of minority stress: Interviews from a population-based longitudinal study. Journal of homosexuality, 63(8), 1019-1040.

Rupp, M., \& Haag, C. (2016). Gleichgeschlechtliche Partnerschaften und Familien [Same-sex partnerships and families]. Handbuch Bevölkerungssoziologie: Wiesbaden: Springer, 327-345.

Savic, I., Berglund, H., \& Lindström, P. (2005). Brain response to putative pheromones in homosexual men. Proceedings of the National Academy of Sciences, 102(20), 7356-7361.

Schilt, K., \& Westbrook, L. (2009). Doing Gender, Doing Heteronormativity: “Gender Normals,” Transgender People, and the Social Maintenance of Heterosexuality. Gender \& society, 23(4), 440-464.

Seligman M.E.P., Steen, T.A., Park, N., \& Peterson, C. (2005). Positive psychology progress: Empirical validation of interventions. American Psychologist. doi: 10.1037/ooo3-066X.60.5.410.

Sheldon, J. P., Pfeffer, C. A., Jayaratne, T. E., Feldbaum, M., \& Petty, E. M. (2007). Beliefs about the etiology of homosexuality and about the ramifications of discovering its possible genetic origin. Journal of homosexuality, 52(3-4), 111-150.

Smith, S., \& Watson, J. (2010). Reading autobiography: A guide for interpreting life narratives. U of Minnesota Press.

Sowe, B. J., Brown, J., \& Taylor, A. J. (2014). Sex and the sinner: Comparing religious and nonreligious same-sex attracted adults on internalized homonegativity and distress. American Journal of Orthopsychiatry, 84(5), 530. 
Steffes, M. C., \& Wagner, C. (2004). Attitudes toward lesbians, gay men, bisexual women, and bisexual men. The Journal of Sex Research, 41, 137-149.

Stern, M. (2016). The pros and cons of gay relationships Retrieved February 8, 2019 from https://www.sbstatesman.com/2016/o2/o9/the-pros-and-cons-of-gay-relationships/.

Suárez-Ortega, M. (2013). Performance, reflexivity, and learning through biographical-narrative research. Qualitative Inquiry, 19(3), 189-200.

Tan, M.L. (2001). Survival Through Pluralism: Emerging Gay Communities in the Philippines. Gay and Lesbian Asia:Culture, Identity, Community. Gerard Sullivan \& Peter A. Jackson (Eds.). The Haworth Press Inc. 117142.

Thibaut, J. W., \& Kelley, H. H. (1959). The social psychology of groups. New York: John Wiley.

Todosijevic, J., Rothblum, E.D., and Solomon, S.E. (2005). Relationship Satisfaction, Affectivity, and Gay-Specific Stressors in Same-Sex Couples Joined in Civil Unions. Psychology of Women Quarterly, 29 (2): 158-66.

Valentine, G., \& Sadgrove, J. (2014). Biographical narratives of encounter: The significance of mobility and emplacement in shaping attitudes towards difference. Urban Studies, 51(9), 1979-1994.

Weill, C. L. (2008). Nature's choice: What science reveals about the biological origins of sexual orientation. Routledge.

Westerfelhaus, R., \& Lacroix, C. (2006). Seeing "straight" through Queer Eye: Exposing the strategic rhetoric of heteronormativity in a mediated ritual of gay rebellion. Critical studies in media communication, 23(5), 426444 .

Wilson, B.D.M., Miller, R.L. (2002). Strategies for managing heterosexism used among African American gay and bisexual men. Journal of Black Psychology. 